\title{
Complete mitochondrial DNA sequence analysis of Bluespotted seabream, Pagrus caeruleostictus (Perciformes: Sparidae)
}

Gyamfua Afriyie ( $\sim$ maamegyamfua95@gmail.com )

Guangdong Ocean University https://orcid.org/0000-0001-8894-0264

\section{Yusong Guo}

Guangdong Ocean University

Felix K.A Kuebutornye

Guangdong Ocean University

Christian Ayisi Larbi

University for Development Studies

Zhongduo Wang

Guangdong Ocean University

Research article

Keywords: luespotted seabream, Pagrus, benthopelagic, Ghana, mitochondrial DNA, Sparidae

Posted Date: October 18th, 2019

DOI: https://doi.org/10.21203/rs.2.16176/v2

License: (c) (1) This work is licensed under a Creative Commons Attribution 4.0 International License.

Read Full License 


\section{Abstract}

Background Bluespotted seabream, Pagrus caeruleostictus is a benthopelagic marine species found in tropical regions and a member of the family Sparidae and genus Pagrus. In this article, a mitochondrial DNA sequence by high-throughput technique, Illumina Hiseq, was carried out on muscle of the above species and determined the complete mitogenome. Samples were obtained from species collected from the coast of Ghana, West Africa.Results The complete mitochondrial DNA sequence was 16,653 bases pairs in length (GenBank Accession number: MN319701) and comprises of 37 genes; 22 transfer RNA genes, 2 ribosomal RNA genes, 13 protein-coding genes as well as a control region as in a typical vertebrate mitochondrial DNA gene. The phylogenetic analysis showed P. caeruleostictus clustered with the clade of P. auriga. Conclusion This research will serve as the foundation for molecular genetic studies of Ghanaian fish species. Moreover, it will contribute to the phylogenetics of class Actinopterygii, order Spariformes, family Sparidae and genus Pagrus.

\section{Background}

Bluespotted seabream, Pagrus caeruleostictus is a bony fish species that belong to class Actinopterygii in the order Perciformes of the family Sparidae and genus Pagrus. Sparidae is family of bony fishes and according to FishBase (www.fishbase.se) and Integrated Taxonomic Information System (www.itis.gov/), 38 genera and 159 species exist within this family including genus Pagrus. However, Nelson and his colleagues reported 37 genera with 148 species within family Sparidae [1] whiles Parenti (2019) stated 426 present in family Sparidae consisting of 166 valid species in 39 genera, 5 subfamilies and 260 synonyms. Statistically, more than one third of this species are endemic along the coast of South Africa [2]. A total of 6 species are classified under genus Pagrus; P. caeruleostictus (Valenciennes, 1830), P. major (Temminck and Schlegel, 1843), P. pagrus (Linnaeus, 1758), P. africanus (Akazaki, 1962), P. auratus (Forster, 1801) and P. auriga (Valenciennes, 1843) [3,4 www.fishbase.org]. Apart from P. major and P. auratus, which are native to the Northwest Pacific and Indo-Pacific respectively, [3; www.fishbase.org], the remaining species are distributed in the Atlantic Ocean and the Mediterranean Sea. The Bluespotted seabream, $P$. caeruleostictus is a localized species of the eastern Atlantic Ocean, from Portugal to Angola, including the area around the Canaries, and also in warmer parts of the Mediterranean (Figure 1), aside from the Black Sea [4, 5 https://www.fishbase.in/summary/4540]. Conversely, in 2015, Yongxia and his colleagues, 
discovered P. caeruleostictus in Chinese coastal waters precisely in the South China Sea. They associated the presence of these species to anthropogenic activities due to the low possibility to have expanded naturally from the eastern Atlantic to the South China Sea coupled with its absence in the Indian or Pacific Oceans [6].

As a high economic species, $P$. caeruleostictus is a benthopelagic marine species found in tropical regions. Commonly, they inhabit in rubble and sandy areas with a depth range of 15-50 $\mathrm{m}$. The matured generation usually inhabit in the deeper part of this range while the young individuals can be located in the inshore areas. At full maturity, P. caeruleostictus attains an average standard length and a weight of $60 \mathrm{~cm}$ and $5 \mathrm{~kg}$ respectively. After two years of spawning, the young ones become sexually matured. Due to their oceanodromous nature, gravid fish migrate to shallow parts of the ocean with soft bottoms to spawn. Bivalves, crustaceans and other finfish are the principal feeds P. caeruleostictus survive on $[2,7]$. This

Figure 1: Global geographic distribution of $P$. caeruleostictus (FAO Fisheries and Aquaculture Department website. Cited on July 16 ${ }^{\text {th }}, 2019$ https://www.aquamaps.org/)

Over the years, the mitochondrial genome sequence and analysis has evolved and keeps growing day-after-day due to increasing technological advancement in molecular biology [8-10]. Moreover, it has become less expensive and has gained appreciable recognition in the field of molecular biology. Cytochrome c oxidase I (Cox1) gene has ability of rapid mutation and its sequences remain unchanged even within closely related species [11]. In view of this, several researchers have used Cox1 gene as a marker for species DNA barcoding [12-14]. Different studies have reported that the intraspecific variation of Cox1 barcodes is small and highly distinguished from interspecific variation [18-20]. Additionally, complete mitogenome is utilized as a better marker in the study of phylogenetic analysis because it provides better phylogenetic resolution with high accuracy relative to traditional method of using single mitochondrial gene markers, for example, the control region $(C R)$ and cytochrome b (cyt b) $[9,18-20]$ and can also distinguish intraspecific species with. The control region is also known as D-loop, relating to the structure formed when mitochondrial DNA replicates. This is a non-coding sequences region which functions as replication and transcription regulator within a mitogenome. 
This region shows high mutation rate and therefore acts as a dominant region to determine intra-species variations [21].

Even though mitochondrial genome sequence has evolved rapidly and has become an ubiquitous technique in evolutionary studies of species, until now no molecular-based evolution studies has been conducted on P. caeruleostictus hence the need for this research. To understand the evolutionary and systematics of $P$. caeruleostictus within the family Sparidae and genus Pagrus, the complete mitogenome sequence was determined with highthroughput sequencing technology (Illumina Hiseq) and studied. Additionally, a phylogenetic analysis based on the $\operatorname{cox} 1$ data was carried out on this species together with

other species from Sparidae to investigate the phylogenetic position of $P$. caeruleostictus within the family Sparidae. The findings of this research outlined in this article will facilitate future investigations on population genetics studies and phylogenetic relationships of species within the Sparidae family and Pagrus genus.

\section{Results}

\section{Mitogenome structure}

The complete mitogenome of $P$. caeruleostictus was determined in this study. This mitogenome contains 37 genes (Table 1) which include 22 transfer RNA genes, 2 ribosomal RNA genes, 13 protein-coding genes in addition to a control region according to a characteristic vertebrate mitochondrial DNA gene [10, 22].

Table 1: 37 genes present in P. caeruleostictus 


\begin{tabular}{|c|c|c|c|c|c|c|c|}
\hline Name & Position & Strand & $\begin{array}{l}\text { Length } \\
\text { (bp) }\end{array}$ & $\begin{array}{l}\text { Start } \\
\text { codon }\end{array}$ & $\begin{array}{l}\text { Stop } \\
\text { codon }\end{array}$ & Anticodon & $\begin{array}{l}\text { Intergenic } \\
\text { nucleotide }\end{array}$ \\
\hline $\operatorname{trnF}(\mathrm{ttc})$ & $1-68$ & $\mathrm{~N}$ & 68 & & & GAA & \\
\hline rrnS & 69-1022 & $\mathrm{N}$ & 954 & & & & -1 \\
\hline \multirow[t]{2}{*}{$\operatorname{trnV}$ (gta) } & 1022- & $\mathrm{N}$ & 72 & & & TAC & 39 \\
\hline & 1093 & & & & & & \\
\hline \multirow[t]{2}{*}{ rrnL } & 1133- & $\mathrm{N}$ & 1658 & & & & \\
\hline & 2790 & & & & & & \\
\hline \multirow[t]{2}{*}{$\operatorname{trnL} 2(\mathrm{tta})$} & 2791- & $\mathrm{N}$ & 73 & & & TAA & \\
\hline & 2863 & & & & & & \\
\hline \multirow[t]{2}{*}{ nad1 } & 2864- & $\mathrm{N}$ & 975 & ATG & TAA & & 5 \\
\hline & 3838 & & & & & & \\
\hline \multirow[t]{2}{*}{ trnI(atc) } & 3844- & $\mathrm{N}$ & 70 & & & GAT & -1 \\
\hline & 3913 & & & & & & \\
\hline \multirow[t]{2}{*}{$\operatorname{trnQ}(\mathbf{c a a})$} & 3913- & $\mathrm{J}$ & 71 & & & TTG & -1 \\
\hline & 3983 & & & & & & \\
\hline \multirow[t]{2}{*}{ trnM(atg) } & 3983- & $\mathrm{N}$ & 70 & & & CAT & \\
\hline & 4052 & & & & & & \\
\hline \multirow[t]{2}{*}{ nad2 } & 4053- & $\mathrm{N}$ & 1047 & ATG & TAA & & -1 \\
\hline & 5099 & & & & & & \\
\hline \multirow[t]{2}{*}{$\operatorname{trn} W(\operatorname{tg} a)$} & 5099- & $\mathrm{N}$ & 70 & & & TCA & 1 \\
\hline & 5168 & & & & & & \\
\hline \multirow[t]{2}{*}{$\operatorname{trn} A(g c a)$} & 5170- & $\mathrm{J}$ & 69 & & & TGC & 1 \\
\hline & 5238 & & & & & & \\
\hline \multirow[t]{2}{*}{$\operatorname{trnN}(a a c)$} & 5240- & $\mathrm{J}$ & 74 & & & GTT & 4 \\
\hline & 5313 & & & & & & \\
\hline \multirow[t]{2}{*}{$\operatorname{trn} C(\operatorname{tg} c)$} & 5349- & $\mathrm{J}$ & 66 & & & GCA & \\
\hline & 5414 & & & & & & \\
\hline \multirow[t]{2}{*}{$\operatorname{trn} Y(\operatorname{tac})$} & 5415- & $\mathrm{J}$ & 70 & & & GTA & 1 \\
\hline & 5484 & & & & & & \\
\hline
\end{tabular}


$\operatorname{cox} 1$

5486

N

1563

GTG

AGG

$-9$

7048

trnS2(tca)

7040-

71

TGA

2

7110

$7113-$
7185

$\operatorname{cox} 2$

7194-

N

691

ATG

T(AA)

7884

trnK(aaa)

7885-

$\mathrm{N}$

74

TTT

1

7958

atp8

7960-

N

168

ATG

TAA

8127

atp6

8118-

N

684

ATG

TAA

$-1$

8801

$\operatorname{cox} 3$

8801-

N

786

ATG

TAA

$-1$

9586

trnG(gga)

9586-

N

72

TCC

9657

nad3

9658-

N

351

ATG

TAG

10008

trnR(cga) 10007-

71

TCG

10077

nad4l

10078

N

297

ATG

TAA

$-7$

10374

nad4

10368-

N

1381

ATG

$\mathrm{T}(\mathrm{AA})$

11748

$\operatorname{trnH}(\mathrm{cac})$

$11749-$

N

69

GTG

11817

trnS1(agc) 11818-

$\mathrm{N}$

68

GCT

6

11885 


\begin{tabular}{|c|c|c|c|c|c|c|c|}
\hline \multirow[t]{2}{*}{$\operatorname{trnL1}$ (cta) } & 11892- & \multirow[t]{2}{*}{$\mathrm{N}$} & \multirow[t]{2}{*}{73} & & & \multirow[t]{2}{*}{ TAG } & \multirow{4}{*}{-4} \\
\hline & 11964 & & & & & & \\
\hline \multirow[t]{2}{*}{ nad5 } & 11965- & $\mathrm{N}$ & 1839 & ATG & TAA & & \\
\hline & 13803 & & & & & & \\
\hline \multirow[t]{2}{*}{ nad6 } & 13800- & $\mathrm{J}$ & 522 & ATG & TAA & & \\
\hline & 14321 & & & & & & \\
\hline \multirow[t]{2}{*}{$\operatorname{trn} E$ (gaa) } & $14322-$ & $\mathrm{J}$ & 69 & & & TTC & 4 \\
\hline & 14390 & & & & & & \\
\hline \multirow[t]{2}{*}{ Cob } & 14395- & $\mathrm{N}$ & 1141 & ATG & $\mathrm{T}(\mathrm{AA})$ & & \\
\hline & 15535 & & & & & & \\
\hline \multirow[t]{2}{*}{$\operatorname{trnT}(\mathrm{aca})$} & 15536- & $\mathrm{N}$ & 74 & & & TGT & -1 \\
\hline & 15609 & & & & & & \\
\hline \multirow[t]{2}{*}{$\operatorname{trn} P(c c a)$} & 15609- & $\mathrm{J}$ & 70 & & & TGG & \\
\hline & 15678 & & & & & & \\
\hline
\end{tabular}

The circle genome is $16,653 \mathrm{bp}$ in length (Figure 2) which falls within the range of a typical vertebrate with the base composition of $27.92 \% \mathrm{~A}, 28.67 \% \mathrm{C}, 16.47 \% \mathrm{G}$, and $26.94 \% \mathrm{~T}$ [23]. The complete genome skewed to AT at 0.018 and to GC at -0.27 .

Figure 2: The mitogenome map of $P$. caeruleostictus

The mitochondrial gene arrangement of $P$. caeruleostictus indicated that all genes were encoded on heavy strand $(\mathrm{OH})$ except for NADH dehydrogenase subunit 6 (ND6) and eight tRNA genes (tRNA-Gln, tRNA-Ala, tRNA-Asn, tRNA-Cys, tRNA-Tyr, tRNA-Ser, tRNA-Glu and tRNA-Pro) which occurred on the light strand (OL). This is in confirmation with other previous studies on vertebrate circular mitogenome sequence [24-27]. A total of thirteen (13) complete stop codons (TAA, TAA, AGG, TAA, TAA, TAA, TAG, TAA, TAA and TAA) and three (3) incomplete stop codons; T(AA), T(AA), and T(AA) were used in the protein-coding 
genes. Moreover, it consisted of 22 anticodons; GAA, TAC, TAA, GAT, TTG, CAT, TCA, TGC, GTT, GCA, GTA, TGA, GTC, TTT, TCC, TCG, GTG, GCT, TAG, TTC, TGT, and TGG.

\section{Features of 22 tRNA genes}

During translation, making a protein from mRNA template, tRNA functions as a transporter of nucleotide from mRNA to amino acids. It functions as the bridge between mRNA and amino acid sequence to the ribosome where proteins are constructed [28]. The mitochondrial genome contained 22 tRNA genes (Table 2). The tRNA genes ranged in size from 65 to 75 nucleotides, which allowed the encoded tRNA to fold into the characteristic clover-leaf secondary structure [29].

Table 2: Present tRNA in the complete mitochondrion DNA of P. caeruleostictus 


\begin{tabular}{|c|c|c|c|}
\hline Product & Location & Length & Atypical pairings \\
\hline tRNA-Phe & $1-68$ & 68 & \\
\hline tRNA-Val & $1022-1093$ & 71 & \\
\hline tRNA-Leu & $2791-2863$ & 72 & UAA \\
\hline tRNA-Ile & 3844-3913 & 69 & \\
\hline tRNA-Gln (complement) & 3913-3983 & 70 & \\
\hline tRNA-Met & $3983-4052$ & 69 & \\
\hline tRNA-Trp & $5099-5168$ & 70 & \\
\hline tRNA-Ala(complement) & $5170-5238$ & 68 & \\
\hline tRNA-Asn (complement) & $5240-5313$ & 73 & \\
\hline tRNA-Cys (complement) & $5349-5414$ & 65 & \\
\hline tRNA-Tyr (complement) & $5415-5484$ & 69 & \\
\hline tRNA-Ser & $7040-7110$ & 70 & UGA \\
\hline tRNA-Asp & 7113-7185 & 72 & \\
\hline tRNA-Lys & 7885-7958 & 73 & \\
\hline tRNA-Gly & 9586-9657 & 71 & \\
\hline tRNA-Arg & $10007-10077$ & 70 & \\
\hline tRNA-His & 11749-11817 & 68 & \\
\hline tRNA-Ser & 11818-11885 & 67 & GCU \\
\hline tRNA-Leu & 11892-11964 & 72 & UAG \\
\hline tRNA-Glu (complement) & $14322-14390$ & 68 & \\
\hline tRNA-Thr & 15536-15609 & 73 & \\
\hline tRNA-Pro (complement) & $15609-15678$ & 69 & \\
\hline
\end{tabular}

Features of rRNA

Ribosomal RNA (rRNA) combines with enzyme and proteins to form complex structure within the cytoplasm to form ribosomes which serve as protein synthesis site. These complex structures travel along the mRNA molecule during translation and facilitate the assembly of amino acids to form a polypeptide chain [30]. The ribosomal RNA (rRNA) 
identified within the genome were 12S rRNA located at $69 \mathrm{bp}$ to $1021 \mathrm{bp}$ consisting $952 \mathrm{bp}$ and 16S rRNA which also stationed at $1094 \mathrm{bp}$ to $2790 \mathrm{bp}$ and made up of $1696 \mathrm{bp}$.

\section{Features of protein-coding genes}

As is other vertebrate, a total of 13 protein-coding genes were present in the mitogenome of P. caeruleostictus. Within the obtained 13 protein-coding genes, 4 of them were paired, located adjacently to each other; atp8-atp6, atp6-cox3, nad41-nad4, and nad5-nad6. Apart from atp6-cox3, all pairs had some overlap genes between them. The length of overlap between these 3 cases, atp8-atp6, nad4l-nad4, and nad5-nad6 were 9 bp, 6 bp and 3 bp respectively (Table 3). All protein genes had an ATG initiation codon except for the cytochrome oxidase subunit I (cox1) gene which had GTG as its initiation codon. Table 3: Characteristics of the protein-coding genes

\begin{tabular}{lllllllll} 
Region & A\% & C\% & G\% & T\% & A+T\% & G+C\% & AT skew & GC skew \\
\hline Rrns & 30.19 & 25.79 & 22.54 & 21.49 & 51.68 & 48.32 & 0.168 & -0.067 \\
Rrnl & 33.78 & 24.43 & 20.99 & 20.81 & 54.58 & 45.42 & 0.238 & -0.076 \\
nad1 & 25.33 & 32.1 & 14.87 & 27.69 & 53.03 & 46.97 & -0.044 & -0.367 \\
nad2 & 25.69 & 36.1 & 12.51 & 25.69 & 51.38 & 48.62 & 0 & -0.485 \\
cox1 & 24.12 & 26.36 & 18.43 & 31.09 & 55.21 & 44.79 & -0.126 & -0.177 \\
cox2 & 27.79 & 27.5 & 16.79 & 27.93 & 55.72 & 44.28 & -0.003 & -0.242 \\
atp8 & 28.57 & 35.12 & 12.5 & 23.81 & 52.38 & 47.62 & 0.091 & -0.475 \\
atp6 & 23.1 & 30.85 & 13.45 & 32.6 & 55.7 & 44.3 & -0.171 & -0.393 \\
cox3 & 25.95 & 29.9 & 16.79 & 27.35 & 53.31 & 46.69 & -0.026 & -0.281 \\
nad3 & 16.66 & 34.19 & 15.95 & 30.2 & 49.86 & 50.14 & -0.211 & -0.364 \\
nad41 & 21.21 & 34.01 & 15.49 & 29.29 & 50.51 & 49.49 & -0.16 & -0.374 \\
nad4 & 26.29 & 31.21 & 13.9 & 28.6 & 54.89 & 45.11 & -0.042 & -0.384 \\
nad5 & 28.98 & 30.29 & 13.32 & 27.41 & 56.39 & 43.61 & 0.028 & -0.389 \\
nad6 & 18.39 & 14.75 & 27.97 & 38.89 & 57.28 & 42.72 & -0.358 & -0.309 \\
Cob & 25.07 & 30.24 & 14.99 & 29.71 & 54.78 & 45.22 & -0.085 & -0.337 \\
\hline
\end{tabular}


The D-loop of P. caeruleostictus was positioned at the end of tRNA-Pro (15679 to 16653) with a length of $974 \mathrm{bp}$. This correlates with other literature on teleost complete mitochondrial sequence [10, 31-33]. However, according to available literature, the D-loop in some vertebrates are located between tRNA-Pro and tRNA-Phe [34-36]. Conserved Sequence Blocks (CSBs) and High Variational Blocks (HVBs) were the findings of the multiple sequence alignment of the D-loops using D. rerio (GenBank Accession number: NC_002333.2) as the reference.

Table 4: Sequence of conserved regions of $P$. caeruleostictus and other teloest with $D$. rerio as reference.

\begin{tabular}{|c|c|c|c|c|c|c|c|c|}
\hline Element & Species & \multicolumn{7}{|c|}{ Sequence } \\
\hline \multirow{7}{*}{ CSB-1 } & \multirow{7}{*}{$\begin{array}{l}\text { Danio rerio } \\
\text { Pagrus caeruleotictus } \\
\text { Oryzias curvinotus } \\
\text { Gobiopterus lacustris } \\
\text { Brycon henni } \\
\text { Trichiurus lepturus } \\
\text { Lutjanus russellii }\end{array}$} & $\bar{C}$ & & & & & & $\bar{T}$ \\
\hline & & $\mathrm{T}$ & & & & & & C \\
\hline & & . & & & & & & $\mathrm{C}$ \\
\hline & & • & . & . & & & & $\mathrm{C}$ \\
\hline & & $\mathrm{T}$ & . & & & & & $\mathrm{C}$ \\
\hline & & $\mathrm{T}$ & & & & & & C \\
\hline & & A & . & & & & & C \\
\hline \multirow[t]{7}{*}{ CSB-2 } & \multirow{7}{*}{$\begin{array}{l}\text { Danio rerio } \\
\text { Pagrus caeruleotictus } \\
\text { Oryzias curvinotus } \\
\text { Gobiopterus lacustris } \\
\text { Brycon henni } \\
\text { Trichiurus lepturus } \\
\text { Lutjanus russellii }\end{array}$} & G & C & & & & & A \\
\hline & & . & . & . & & & & \\
\hline & & r & . & . & & & & \\
\hline & & & . & & & & & \\
\hline & & . & & & & & & \\
\hline & & A & . & & & & & \\
\hline & & & 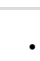 & & & & & \\
\hline \multirow[t]{7}{*}{ CSB-3 } & \multirow{7}{*}{$\begin{array}{l}\text { Danio rerio } \\
\text { Pagrus caeruleotictus } \\
\text { Oryzias curvinotus } \\
\text { Gobiopterus lacustris } \\
\text { Brycon henni } \\
\text { Trichiurus lepturus } \\
\text { Lutjanus russellii }\end{array}$} & $\mathrm{G}$ & ( & & & & & $A$ \\
\hline & & A & & & & & & \\
\hline & & & . & & & & & \\
\hline & & - & & & & & & \\
\hline & & A & & & & & & C \\
\hline & & A & & & & & & \\
\hline & & A & & & & & $\mathrm{G}$ & \\
\hline
\end{tabular}

Note: Dot represent the same nucleotide as the reference species, $D$. rerio

\section{Phylogenetic analysis}

In order to ascertain the evolutionary features of P. caeruleostictus mitogenomes, complete mitochondrial and Cox1 sequences of other species from Order Perciformes were downloaded in FASTA format from the database of National Center for Biotechnology Information (NCBI-Blast) (https://blast.ncbi.nlm.nih.gov) and Barcode of Life Database 
(BOLD) (http://www.barcodinglife.org) systems respectively, these database contains comprehensive data on species gene sequence for molecular phylogenetic analysis [37]. Using MEGA version 6.0v, nucleic acid sequences were aligned using ClustalW with the Alignment Explorer tool and constructed a neighbor-joining trees at the order-level [38]. As shown in Figure 3 and 4 below, $P$. caeruleostictus clustered closest with $P$. auriga as supported by a high bootstrap value (99\%) in both cases.

Figure 3: Neighbor-joining phylogenetic tree based on Cox1 sequences.

Figure 4: Neighbor-joining phylogenetic tree based on complete mitochondrial sequences with $L$. fulviflamma as the out group.

\section{Discussion}

Illumia HiSeq technology utilized during the sequencing is one of high-throughput sequencing (HTS) methods, also known as next-generation sequencing. Successfully, this technique was able to sequence the complete mitochondrial DNA from the specimen, obtaining a total read of $16,653 \mathrm{bp}$ length. This is similar to the mitogenomic length of other vertebrates including teleost [22, 39-41]. A major disadvantage of this method is the price involved due to the use of sophisticated equipment and highly skilled personnel. Furthermore, the cost for sequencing is determined by the types of libraries desired, either single-end read, paired-end read or mate-pair libraries as well as the number of cycles requested [42].

The MitoAnnotation detected the presence of 2 tRNA-Leu and 2 tRNA-Ser (Table 2). The same result was obtained in a study on Lutjanus russelli [34]. Both species belong to the Order Perciformes.

The result of the D-loop multiple sequence alignment depicts the presence of both Conserved Sequence Blocks (CSBs) (Table 4) and High Variation Blocks (HVBs). Furthermore, an extended termination associated sequence domain (ETAS), a central conserved sequence block domain (CSB-D, CSB-E and CSB-F) and a conserved sequence block domain (CSB-1, CSB-2 and CSB-3) were identified. This result is same as the result of 
the other teleost compared with [10,31, 34, 39, 43, 44]. Additionally, the non-coding region with a light strand (L-strand), was located amongst a cluster of tRNA genes (the WANCY region), that is between the tRNA- Asn and tRNA-Cys genes as found in a most vertebrate [45]. This consisted of $31 \mathrm{bp}$ in length (TCTTTCCCCCGCCCTGGGGGCGGAAAGGCG).

The resultant phylogenies (Figure 3 and 4) indicated $P$. caeruleostictus shares a close relationship with $P$. auriga. Additionally, in Figure 4, Pagrus species together with Dentex species formed a clade based on complete mitogenome representing these genera evolved from a common ancestor. This result confirms the findings on phylogenetic relationship between Pagrus species and Dentex species[46-48]. With the formation of a monophyletic group between both genera, authors hypothesize a degree of resemblance not only morphologically but on the molecular level. In view on this, further molecular based studies within these genera are recommended since both genera belong to the same family, Sparidae.

\section{Conclusions}

In the current study, muscle of bluespotted seabream, $P$. caeruleostictus, was sampled from the landings of commercial boats from the coast of Ghana. Muscle sample was subjected to high-throughput sequencing (Illumina Hiseq) and successfully acquired the complete mitogenome of this species. This article throws more light on the taxonomy, systematics, global distribution and evolution based on complete mitogenome phylogenetics analysis of P. caeruleostictus. This research will contribute to the phylogenetics of class Actinopterygii, order Perciformes, family Sparidae and genus Pagrus. As a novel published paper on the complete mitogenome of $P$. caeruleostictus, it lays a foundation for further research and a better understanding on the molecular genetics of $P$. caeruleostictus. Furthermore, it illustrates the beneficial effects of an increased taxon sampling coupled with the use of more realistic nucleotide and amino acid substitution models for the reconstruction of animal phylogeny.

\section{Materials And Method}

\section{Specimen sampling and sampling site}


In the present study, $P$. caeruleostictus specimen was sampled from the coast of SekondiTakoradi, Ghana, West Africa in December 2018. Geographically, samples were taken from the coordinates $4^{\circ} 54^{\prime} 59^{\prime \prime} \mathrm{N}, 1^{\circ} 42^{\prime} 06^{\prime \prime} \mathrm{W}$ from the landings of a commercial fishing boat. A total of 18 samples were collected and next generation sequencing was carried out on one to obtain the complete mitogenome.

The muscle was used to extract DNA [49]. The specimen was stored in absolute ethanol whiles been transported to the laboratory where it was stored in $-20{ }^{\circ} \mathrm{C}$ refrigerator upon arrival until used.

\section{DNA Extraction, Amplification, and Sequencing}

Total DNA was extracted using the method of proteinase $\mathrm{K}$ digestion from fish muscle. The DNA quality test was carried out to determine the concentration and purity using Thermo Scientific NanoDrop 2000. The integrity was detected by agarose gel electrophoresis and Agilent Bioanalyzer (Agilent Technologies, CA, USA). Covaris machine was used to interrupt DNA and for DNA fragmentation. Using a combination of 3'-5' exonuclease and polymerase, DNA fragments were cleaved with a protruding end for double end repair. A single base "A" was introduced at the 3 end, and the 3 terminus of the linker containing a single base "T ", enabling the DNA fragments and linkers to connect through "A" complementary pairing. DNA fragments and linker were attached to ligase. Enriched DNA fragments with ligated ends and simultaneously amplified DNA libraries were selected after library PCR amplification and the quality was inspected using Agilent Bioanalyzer to detects library size and quantifies total library concentration. Illumina Hiseq was selected for sequencing. The single-strand library was used as a template for bridge PCR amplification and sequencing while sequencing.

The complete mitochondrion DNA sequence was submitted to the GenBank database and can be accessed via the accession number MN319701.

\section{Sequence assembling and Annotation}

Multiple sequence analysis was carried out on the D-loop region of $P$. caeruleostictus together with D-loop regions from other species; Trichiurus nanhaiensis, Oryzias curvinotus, Lutjanus russellii, Gobiopterus lacustris and Brycon henna using MEGA version $6.0 \mathrm{v}[38]$. 


\section{Declarations}

\section{Ethics approval and consent to participate}

The fish specimen under study in this article was obtained from commercial boats and is not involve endangered or protected species (www.iucnredlist.org). Samples collection and maintenance were performed in strict accordance with the recommendations of the government of Ghana on Conservation, Management and Utilization of Ghana's wildlife resources. No ethics approval was required for the public sequence data used.

\section{Consent for publication}

Not applicable

\section{Availability of data and materials}

The article contains all of the datasets supporting the results whiles the sequence obtained from the species under study was submitted and assigned the accession number MN319701 on GenBank. Supplementary files are uploaded together with the manuscript.

1. Additional file 1: Sequence file

2. Additional file 2: Figure S1. Map of mitogenome map (http://mitofish.aori.u-tokyo.ac.jp)

3. Additional file 3: Figure S2. Multiple sequence analysis of caeruleostictus with both Pagrus species and other teleost based on Cox1 sequences (MEGA file)

4. Additional file 4: Figure S3. Multiple sequence analysis of caeruleostictus with other teleost based on complete mitochondrial DNA sequences (MEGA file)

5. Additional file 5: Table S1. Multiple sequence analysis of caeruleostictus and other teloest with $D$. rerio as reference for conservered sequence block (MEGA file)

6. Additional file 6: Table S2. List of species examined in this study with GenBank accession numbers

\section{Competing interests}

The authors report no competing interest.

\section{Funding}

This work was supported by grants from the National Natural Science Foundation of China (31201996, 41806195), Guangdong Talent Project (Yq2013089), and Start-up Fund from 
Guangdong Ocean University (GDOU2013050307).

\section{Authors' contributions}

ZW, GA, and YG conceived and designed the study. CAL collected the sample. GA, ZW and FKAK carried out the data analysis, molecular work and wrote the article. ZW supervised this study.

\section{Acknowledgements}

Authors would like to express our gratitude to Mr. Huipai Peng for his assistance during the production of this paper.

\section{References}

1. Nelson JS, Grande TC, Wilson MVH. Fishes of the World. 5th editio. John Wiley \& Sons, Hoboken, N.J.; 2016.

2. Parenti P. An annotated checklist of the fishes of the family Sparidae An annotated checklist of the fishes of the family Sparidae. FishTaxa. 2019;4:47-98.

3. Kraljevic M, Dulc J. On the record of red seabream Pagrus major ( Temminck and Schlegel , 1843 ) (Osteichthyes: Sparidae ) in the Adriatic Sea. Sci Mar. 2007;71:15-7.

4. Froese R, Pauly D (eds. . FishBase. Pagrus major (Temminck \& Schlegel, 1843). Accessed through: World Register of Marine Species at: World Wide Web electronic publication. version (02/2019). 2019. http://www.marinespecies.org/aphia.php? $\mathrm{p}=$ taxdetails\&id $=273976$ on 2019-07-23.

5. Whitehead PJP, Bauchot ML, Hureau JC, Nielsen J, Tortonese E (Eds). Fishes of the North-Eastern Atlantic and the Mediterranean, vols. I-III. . UNESCO, Paris; 1986. p. 1473.

6. Chen Y, Liu J, Wu R. A new record of blue-spotted seabream Pagrus caeruleostictus from Chinese coastal waters documented from morphology and DNA barcoding. Chinese J Oceanol Limnol. 2015;33:500-5.

7. Hamida NBH, Abdallah OBHH Ben, Ghorbel M, Jarboui O, Missaoui H. The feeding habits of the bluespotted seabream, Pagrus caeruleostictus (Valenciennes, 1830), in the Gulf of Gabes (Central Mediterranean). Rev Fish Sci. 2010;18:65-72.

8. Asaki TAS, Ikaido MAN, Amilton HEH, Oto MUG, Ato HIK, Anda NAK, et al. Mitochondrial Phylogenetics and Evolution of Mysticete Whales. Syst Biol. 2005;54:7790.

9. Duchene S, Archer FI, Vilstrup J, Caballero S, Morin PA. Mitogenome Phylogenetics : The Impact of Using Single Regions and Partitioning Schemes on Topology , 
Substitution Rate and Divergence Time Estimation. PLoS One. 2011;6:1-13.

10. Landinez-Garcia RM, Alzate JF, Ma'rquez EJ. Complete mitogenome of the Neotropical fish Brycon henni , Eigenmann 1913 ( Characiformes , Bryconidae ). Mitochondrial DNA Part A. 2016;1394:2259-60.

11. Abbas EM, Soliman T, El-Magd MA, Farrag MMS, Ismail RF, Kato M. Phylogeny and DNA Barcoding of the Family Sparidae Inferred from Mitochondrial DNA of the Egyptian Waters. J Fish Aquat Sci. 2017;12:73-81.

12. Pietan LL, Spradling TA, Demastes JW. The Mitochondrial Cytochrome Oxidase Subunit I Gene Occurs on a Minichromosome with Extensive Heteroplasmy in Two Species of Chewing Lice, Geomydoecus aurei and Thomomydoecus minor. PLoS One. 2016;11:e0162248-e0162248. doi:10.1371/journal.pone.0162248.

13. Kochzius M, Seidel C, Antoniou A, Botla SK, Campo D, Cariani A, et al. Identifying Fishes through DNA Barcodes and Microarrays. PLoS One. 2010;5:e12620-e12620. doi:10.1371/journal.pone.0012620.

14. Ward RD, Zemlak TS, Innes BH, Last PR, Hebert PD. DNA barcoding Australia's fish species. Philos Trans R Soc B. 2005;360:1847-57.

15. Lakra WS, Singh M, Goswami M, Gopalakrishnan A, Lal K., Mohindra V, et al. DNA barcoding Indian freshMensah, M. A. et al. (2003) 'Study of the impact of Ghana., international trade in fishery products on food security - the case of Ghana'.water fishes. Mitochondrial DNA Part A DNA Mapping, Seq Anal. 2016;27:4510-7. doi:10.3109/19401736.2015.1101540.

16. Ward DR, Hanner V, Hebert PD. The campaign to DNA barcode all fishes, FISH-BOL. J Fish Biol. 2009;74:329-56.

17. Zemlak TS, Ward RD, Connell AD, Holmes BH, Hebert PDN. DNA barcoding reveals overlooked marine fishes. Mol Ecol Resour. 2009;9:237-242.

18. Morin PA, Archer FI, Foote AD, Vilstrup J, Allen EE, Wade P, et al. Complete mitochondrial genome phylogeographic analysis of killer whales (Orcinus orca) indicates multiple species. Genome Res. 2010;20:908-16. doi:10.1101/gr.102954.109.

19. Kappas I, Vittas S, Pantzartzi CN, Drosopoulou E, Scouras G. A Time-Calibrated Mitogenome Phylogeny of Catfish ( Teleostei : Siluriformes ). PLoS One. 2016;11:1-16.

20. Wang ZD, Guo YS, Tan W, Li L, Tang EP, Liu CW, et al. DNA barcoding, phylogenetic relationships and speciation of snappers (genus Lutjanus). Sci China Life Sci. 2010;53:1025-30.

21. Stoneking M, Hedgecock D, Higuchi RG, Vigilant L, Erlich HA. Population variation of human mtDNA control region sequences detected by enzymatic amplification and sequence-specific oligonucleotide probes. Am J Hum Genet. 1991;48:370.

22. Wang Z, Zhongduo W, Yusong G, Wei T, Lu L, Enpu T. DNA barcoding, phylogenetic relationships and speciation of snappers ( genus DNA barcoding, phylogenetic 
relationships and speciation of snappers ( genus Lutjanus ). Sci CHINA Life Sci. 2010;53:1025-30.

23. Stothard P, Wishart DS. Circular genome visualization and exploration using CGView. Bioinformatics. 2005;21:537-9.

24. Krishnan KJ, Turnbull DM. Mitochondrial DNA and genetic disease. BioEssays. 1992;14:763-8.

25. Shi X, Tian P, Lin R, Huang D, Wang J. Characterization of the Complete Mitochondrial Genome Sequence of the Globose Head Whiptail Cetonurus globiceps ( Gadiformes: Macrouridae ) and Its Phylogenetic Analysis. PLoS One. 2016;11:1-17.

26. Yang H, Xia J, Zhang J, Id JY, Zhao H, Wang Q, et al. Characterization of the Complete Mitochondrial Genome Sequences of Three Croakers ( Perciformes, Sciaenidae ) and Novel Insights into the Phylogenetics. Int J Mol Sci. 2018;19:1-25.

27. Alam T, Petit RA, Read TD, Dove ADM. The complete mitochondrial genome sequence of the world ' s largest fi sh, the whale shark ( Rhincodon typus ), and its comparison with those of related shark species. Gene. 2014;:1-6. doi:10.1016/j.gene.2014.01.064.

28. Nissen P, Hansen J, Ban N, Moore PB, Steitz TA. The Structural Basis of Ribosome Activity in Peptide Bond Synthesis. Science (80- ). 2000;289:920-930.

29. Schmidt DJ, Mcdougall C, Schmidt DJ. Complete mitogenomes of five ecologically diverse Australian freshwater fishes Complete mitogenomes of five ecologically diverse Australian freshwater fishes. Mitochondrial DNA Part B Resour. 2019;4:191-3. doi:10.1080/23802359.2018.1545546.

30. Dahlberg AE. The functional role of ribosomal RNA in protein synthesis. Cell. 1986;57:525-9.

31. Wang Z, Long S, Liao J, Huang C, Zhang H, Huang S, et al. Complete mitogenome of Hainan medaka Oryzias curvinotus (Teleostei: Beloniformes) and transcriptional differences between male and female liver. Mitochondrial DNA Part B Resour. 2017;2:157-8. doi:10.1080/23802359.2017.1303340.

32. Andriyono S, Sektiana SP, Alam J, Kim HW. The complete mitochondrial genome of black-spot snapper, Lutjanus fulviflamma (Perciformes: Lutjanidae). Mitochondrial DNA Part B Resour. 2019;4:366-7. doi:10.1080/23802359.2018.1547150.

33. Broughton RE, Milam JE, Roe BA. The complete sequence of the zebrafish (Danio rerio) mitochondrial genome and evolutionary patterns in vertebrate mitochondrial DNA. Genome Res. 2001;11:1958-67.

34. Wang Z, Guo Y, Wang Z, Liu C, Liu Y. Sequencing and analysis of the complete mitochondrial DNA of Russell ' s snapper ( L . russellii ). Prog Nat Sci. 2014;18:1233-8.

35. Kumar A, Gautam KB, Singh B, Yadav P, Gopi GV, Gupta SK. Sequencing and characterization of the complete mitochondrial genome of Mishmi takin (Budorcas 
taxicolor taxicolor) and comparison with the other Caprinae species. Int J Biol Macromol. 2019;137:87-94. doi:https://doi.org/10.1016/j.ijbiomac.2019.06.201.

36. Cecconi F, Giorgi M, Mariottini P. Unique features in the mitochondrial D-loop region of the European seabass Dicentrarchus labrax. Gene. 1995;160:149-55. doi:https://doi.org/10.1016/0378-1119(95)00232-U.

37. Miya M, Friedman M, Satoh TP, Takeshima H, Sado T, Iwasaki W, et al. Evolutionary Origin of the Scombridae (Tunas and Mackerels): Members of a Paleogene Adaptive Radiation with 14 Other Pelagic Fish Families. PLoS One. 2013;8:1-19.

38. Tamura K, Stecher G, Peterson D, Filipski A, Kumar S. MEGA6: Molecular evolutionary genetics analysis version 6.0. Mol Biol Evol. 2013;30:2725-9.

39. Huang C, Dong Z, Long S, Huang S, Zhang H, Wang C, et al. Complete mitogenome of Gobiopterus lacustris (Perciformes: Gobiidae). Mitochondrial DNA Part B Resour. 2019;4:62-3. doi:10.1080/23802359.2018.1536456.

40. Falkenberg M, Larsson NG, Gustafsson CM. DNA replication and transcription in mammalian mitochondria. Annu Rev Biochem. 2007;76:679-699.

41. Bayona-Vásquez NJ, Hernández-Álvarez CA, Glenn T, Domínguez-Domínguez O, UribeAlcocer M, Díaz-Jaimes P. Complete mitogenome sequences of the pacific red snapper (Lutjanus peru) and the spotted rose snapper (Lutjanus gutattus). Mitochondrial DNA Part A DNA Mapping, Seq Anal. 2017;28:223-4.

42. Normand R, Yanai I. An introduction to high-throughput sequencing experiments: Design and bioinformatics analysis. Methods Mol Biol. 2013;1038:1-26.

43. Liu X, Guo Y, Wang Z, Liu C. The complete mitochondrial genome sequence of Trichiurus nanhaiensis (Perciformes: Trichiuridae). Mitochondrial DNA. 2013;24:5167.

44. Zhao L, Gao T, Lu W. Complete mitochondrial DNA sequence of the endangered fish ( Bahaba taipingensis ): Mitogenome characterization and phylogenetic implications. Zookeys. 2015;195:181-95.

45. Seutin G, Lang BF, Mindell DP, Morais R. Evolution of the WANCY region in amniote mitochondrial DNA. Mol Biol Evol. 1994; June:329-39.

46. Ceruso M, Mascolo C, Palma G, Anastasio A, Pepe T, Sordino P. The complete mitochondrial genome of the common dentex, Dentex dentex (perciformes: Sparidae). Mitochondrial DNA Part B Resour. 2018;3:391-2. doi:10.1080/23802359.2018.1450675.

47. Mascolo C, Ceruso M, Palma G, Anastasio A, Pepe T, Sordino P. The complete mitochondrial genome of the Pink dentex Dentex gibbosus (Perciformes: Sparidae). Mitochondrial DNA Part B Resour. 2018;3:525-6. doi:10.1080/23802359.2018.1467230. 
48. Mascolo C, Ceruso M, Chirollo C, Palma G, Anastasio A, Sordino P, et al. The complete mitochondrial genome of the Angolan dentex Dentex angolensis (Perciformes:

Sparidae). Mitochondrial DNA Part B Resour. 2019;4:1245-6. doi:10.1080/23802359.2019.1591248.

49. Guo Y, Bai Q, Yan T, Wang Z, Liu C. Mitogenomes of genus Pristipomoides, Lutjanus and Pterocaesio confirm Caesionidae nests in Lutjanidae. Mitochondrial DNA. 2014;1736:1-2.

50. Russell B. Pagrus caeruleostictus. The IUCN Red List of Threatened Species. e.T170159A1284207. 2014.

\section{Figures}




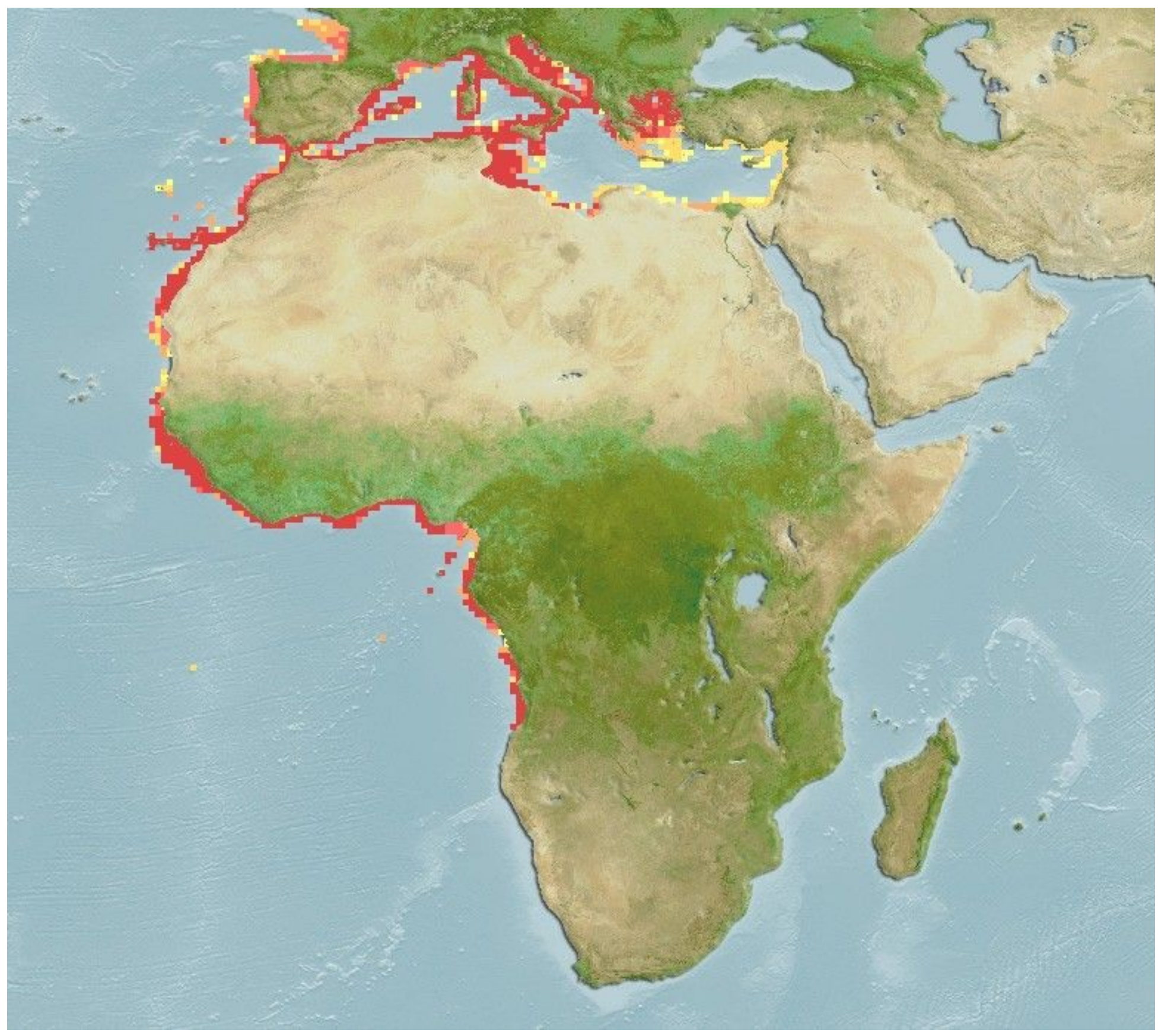

\section{Figure 1}

Global geographic distribution of P. caeruleostictus (FAO Fisheries and Aquaculture Department website. Cited on July 16th, 2019 https://www.aquamaps.org/) Note: The designations employed and the presentation of the material on this map do not imply the expression of any opinion whatsoever on the part of Research Square concerning the legal status of any country, territory, city or area or of its authorities, or concerning the delimitation of its frontiers or boundaries. This map has been provided by the authors. 


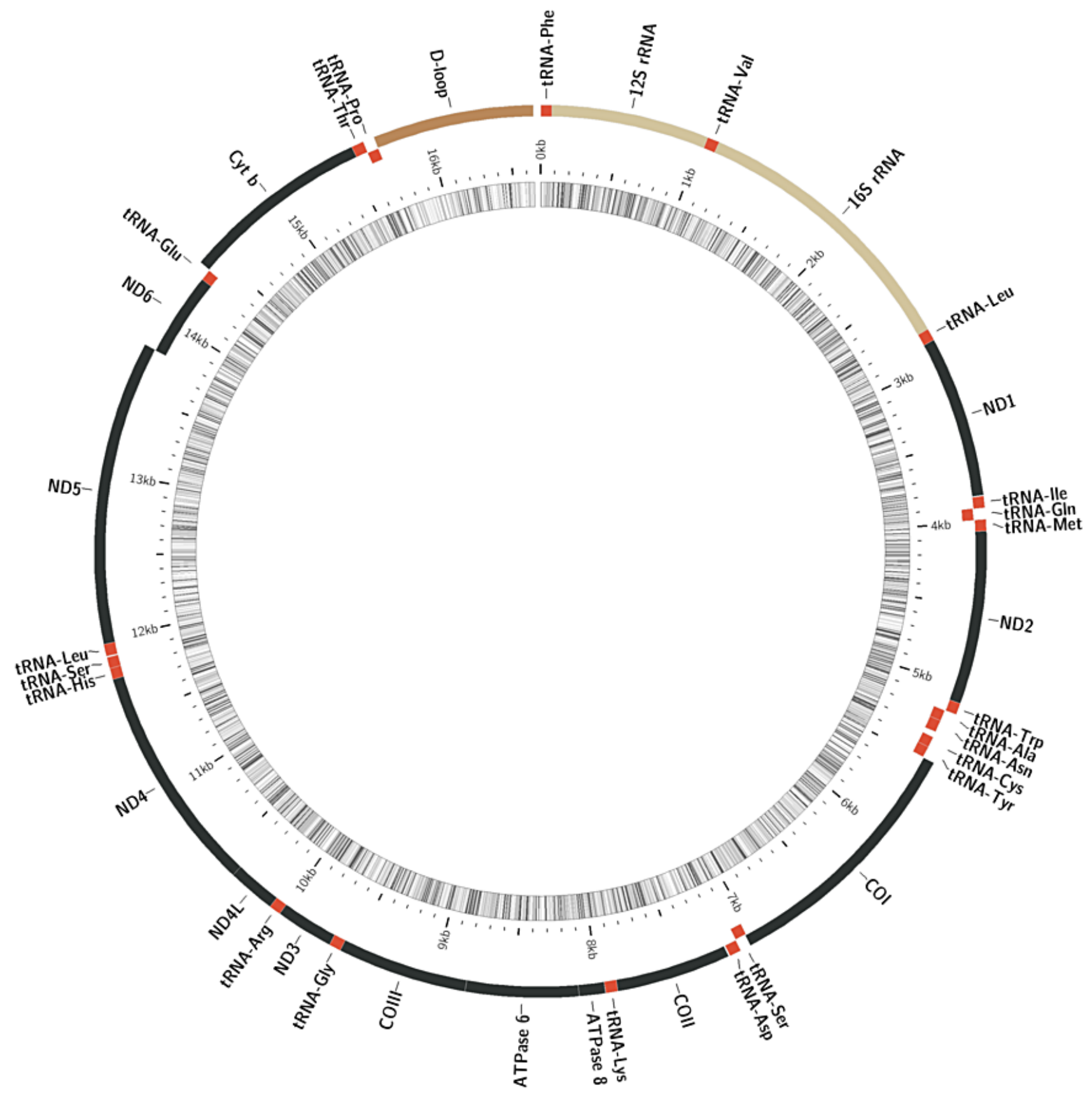

Figure 2

The mitogenome map of P. caeruleostictus 


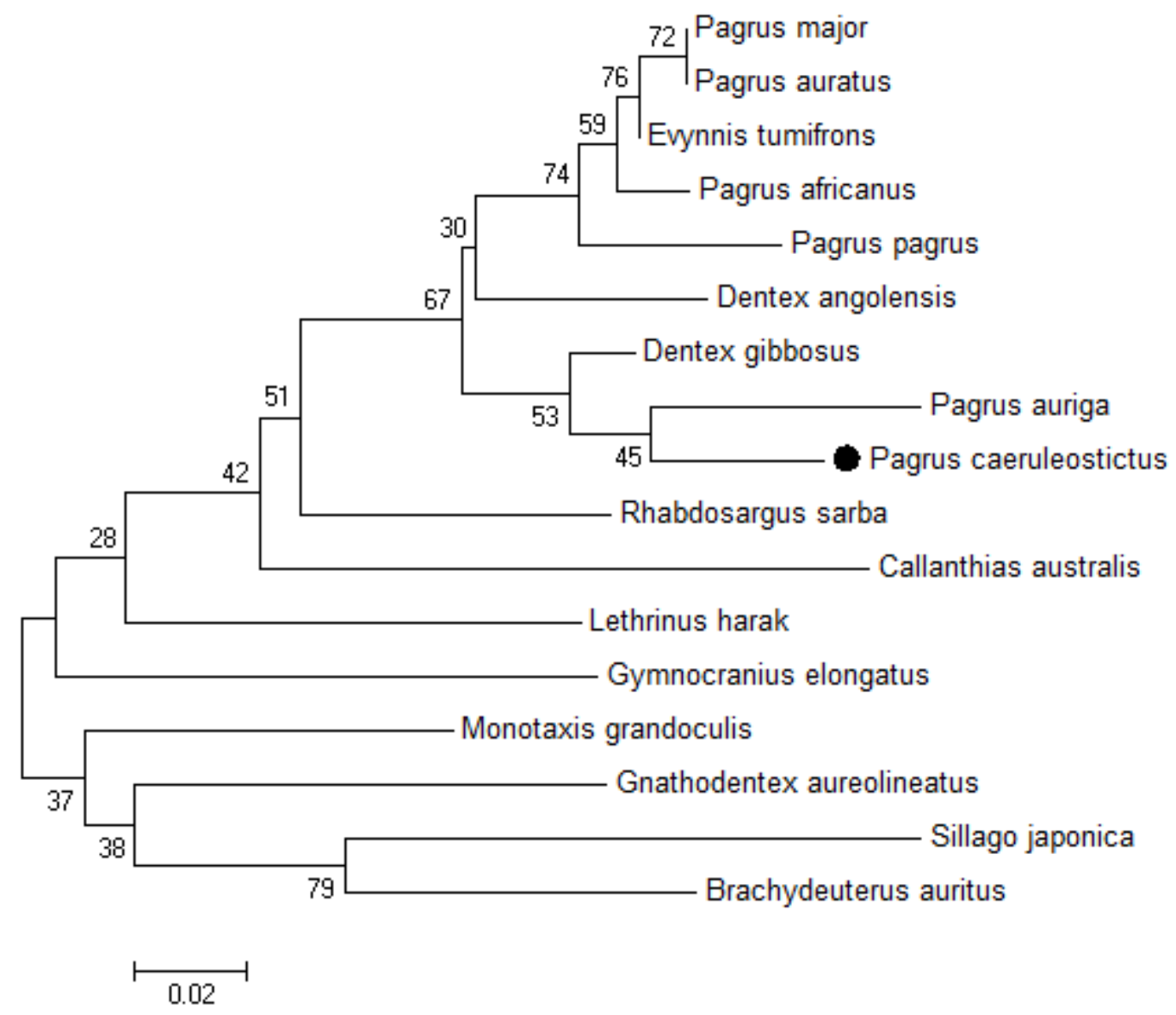

\section{Figure 3}

Neighbor-joining phylogenetic tree based on Cox1 sequences.

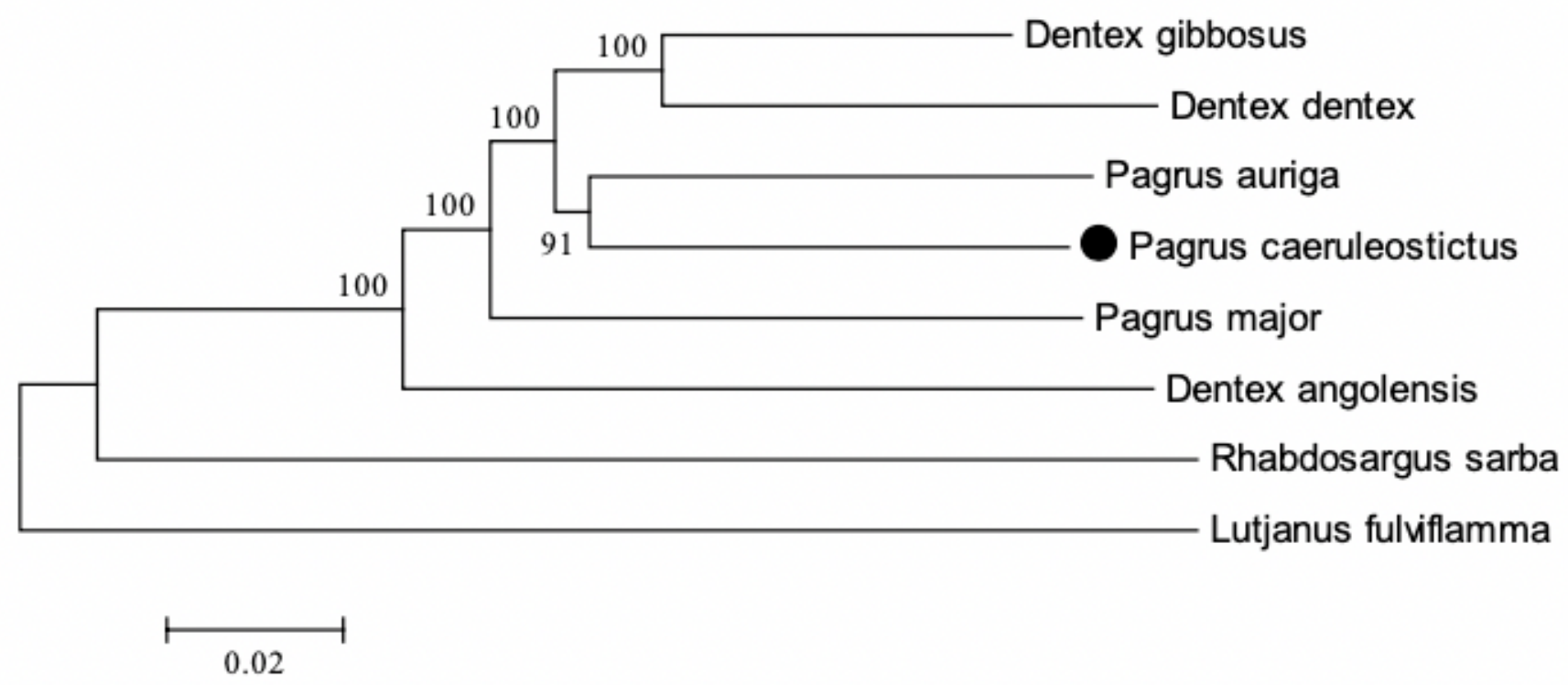

Figure 4 
Neighbor-joining phylogenetic tree based on complete mitochondrial sequences with L. fulviflamma as the out group.

\section{Supplementary Files}

This is a list of supplementary files associated with this preprint. Click to download.

- 4.Multiplesequenceanalysisbasedcompletemitogenome.mas

- 6.ListofSpeciesconsideredinthisstudy.docx

- 1.SequencefileofPagruscaeruleostictus.txt

- 3.MultiplesequenceanalysisbasedonCox1.mas

- 5.MultiplesequenceanalysisforConservedregions.mas 